\title{
Relevance in the Application of IFRS 16 for Financial Statements: Empirical Evidence the Impact of the Financial Method in SMEs
}

\author{
Secinaro Silvana, Brescia Valerio, Iannaci Daniel, Chmet Federico \\ University of Turin, Turin, Italy
}

\begin{abstract}
Leasing is confirmed among the preferred forms of financing by SMEs (Small and Medium Enterprises), even if its use grows both among large companies and private individuals. The stipulated in Europe increased in 2017 by $8.3 \%$ over the previous year. From 1 January 2019 the new accounting standard IFRS 16 is in force, which concerns the accounting of leasing contracts. The new methods of accounting for leasing contracts in the financial statements drawn up based on international accounting standards come into force. In fact, as from 1 January 2019, the IAS adopters are required to apply the new IFRS 16 standard, introduced in place of IAS 17, with the aim of standardizing the methods for recognizing leasing contracts in the financial statements. Scientifically, the most important researches concerning leasing have dealt with the topic focusing on accounting harmonization, accounting for leasing, capitalization of leasing and tax. Through the theoretical analysis and the simulation of our case study we want to answer a question: How the change in the accounting of leases is reflected in the financial statements?
\end{abstract}

Keywords: accounting, IFRS 16, leases, SMEs

\section{Introduction}

Leasing is a contract whereby the lessee is supplied with the asset against payment to the lessor of an instalment; contracts may include the option to extend the lease, they may give the lessee the opportunity to redeem the asset over the life of the contract or from an agreed date, the right of ownership can be transferred at the end of the contract (McConnell \& Schallheim, 1983).

This study examines how the performance of the sector's financial statements would change with the introduction of the IFRS 16 (International Financial Reporting Standard-IFRS 16-Leases) accounting method also, for Italian SMEs, which adopt OICs. In particular, the main objective of this paper is to investigate the implications of leasing accounting standard with a financial method.

The new accounting standard IFRS 16, which concerns the accounting of leasing contracts, came

Secinaro Silvana, Ph.D., associate professor, Department of Management, University of Turin, Turin, Italy.

Brescia Valerio, Ph.D., research fellow, Department of Management, University of Turin, Turin, Italy.

Iannaci Daniel, M.Sc., Ph.D. student, Department of Management, University of Turin, Turin, Italy.

Chmet Federico, M.Sc., Ph.D. student, Department of Management, University of Turin, Turin, Italy.

Correspondence concerning this article should be addressed to Brescia Valerio, Department of Management, University of Turin, C.so Unione Sovietica 218-bis, Turin, Italy. 
into force on 1st of January, 2019. The new standard replaces IAS 17 which intends to introduce a single accounting model for all types of leases as well as overcoming the distinction between financial and operating leases. The amendments have an impact on the accounting operations carried out by the lessees (users), providing for the recording in the balance sheet of the right to use the asset and in the liabilities of the present value of the payments due for the lease. The methods of recognition in the financial statements of lessors remain unchanged. The new methods of accounting for leasing contracts in the financial statements have prepared the following international accounting standards which come into force. Starting from 1st of January, 2019, the IAS adopters are required to apply the new IFRS 16 standard, which are introduced to replace IAS 17 to standardise the methods of recording leasing contracts in the financial statements of the lessees.

With the reform of leasing accounting, the IASB is reacting to the broad criticisms of IAS 17 and is seeking to provide financial statements recipients with a comprehensive and understandable picture of the leasing activities of IFRS users in the future (Toferer, 2018). The core of the reform is the move from the previous risk-benefit approach of IAS 17 to the asset-liability approach of IFRS 16. The "assets and liabilities" approach is based on a uniform accounting model (right of use), whereby in the future, as a rule, all leases and rentals will be reflected in the balance sheet with the corresponding rights of use and liabilities (Joubert, Garvie, \& Parle, 2017; Morales-Díaz \& Zamora-Ramírez, 2018; Öztürk \& Serçemeli, 2016). Accounting rules are no longer based on the economic ownership of the leased asset, but on the rights and obligations arising from a leasing contract (Toferer, 2018).

The definition of lease is broader under IFRS 16 than under current International Accounting Standards (IAS) 17, so companies will need to assess their contracts to see whether potential lease items are covered by the new provisions. The requirements of IFRS 16 state that a contract contains a lease if it "conveys the right to control the use of an identified asset for a period of time in exchange for consideration" (IFRS 16, p. 9) (IASB, 2016). In determining whether a contract contains a lease, businesses will then need to determine whether there is an identified asset and whether they are entitled to obtain all the economic benefits arising from the use of that asset (Cordazzo, Rossi, \& Lubian, 2019; Morales-Díaz \& Zamora-Ramírez, 2018).

Thus, if, for example, the enterprise rents part of a warehouse to store goods, but this area varies according to the space available, then it is unlikely to be classified as a lease under IFRS 16 because no specific asset can be identified. If, however, the company rents a specific unit in the storage facility for a specified period of time, the asset can be identified and therefore the contract contains a lease.

The principle of the prevalence of the substance over the form is provided by the Italian Civil Code (Repubblica Italiana, 1942) and by the Italian accounting standards of Organismo Italiano Contabilità (OIC) specifically with reference to OIC 11 . The introduction of this standard leads to the accounting of leasing operations according to the "financial method" and not according to the "operating method".

However, since Legislative Decree 139/2015 (Repubblica Italiana, 2015) has not made any changes to the information to be provided on the Explanatory Notes to the Financial Statements, in which it is identified as providing information on leasing contracts accounted for using the Operating Method. Therefore in the accounting of financial leasing operations continues to be cases in which the principle of the prevalence of the substance over the form is not yet applicable.

The potential use of the financial method could bring positive perception effects among stakeholders as already demonstrated by Armstrong, Barth, Jagolinzer, and Riedl (2010) through the study about the "Market 


\section{Reaction to the Adoption of IFRS in Europe".}

This is in order to improve the information quality of the transaction and to ensure greater transparency on the debt and on the assets that the companies employ in their operations, and on the risks to which they are exposed through the stipulation of leasing contracts.

The adoption of the new standard will substantially change the current accounting system for leasing operations, increasing, through a more faithful and consistent representation of the instrument, the level of transparency and information effectiveness (Chambers \& Dooley, 2015; Dezzani, Biancone, \& Busso, 2016; Graham \& King, 2013; Lightner, Bosco, DeBoskey, \& Lightner, 2013). Small and medium-sized enterprises are with low accounting quality which has a higher propensity to lease than the purchase of the asset, therefore they are the backbone of the economy (Beatty, Liao, \& Weber, 2010). The underwriting of the leasing instalments stipulated in 2017 is the continuation of a positive trend that has continued since previous years. The number of contracts signed in 2017 amounts to 684 thousand, an increase of about $10 \%$ compared to the previous year that recorded; as regards, however, the value of new contracts, exceeds 26.6 billion euros, the performance is of the contracts, compared to the previous year, has increased by $13 \%$. One of the most significant values recorded concerns buildings under construction at the expense of those already constructed. In particular, an increase in the number of buildings to be constructed was recorded, equal to $17.4 \%$ in the range between 500 thousand and 2.5 million euro (Assilea, 2018).

IAS 17 remained in force until 1st of January, 2019, when the new standard IFRS 16 was introduced. Unlike IAS 17, IFRS 16 imposes a single method of accounting by lessees for leases, i.e. a financial method. The methods of accounting for leases by lessors remain unchanged (Morales-Díaz \& Zamora-Ramírez, 2018). The objective of the International Accounting Standards Board (IASB) is to unify and harmonize accounting standards in order to make the financial statements of companies operating in similar sectors as comparable as possible (Mechelli, 2009). In order to a better understanding, the study links the principle of the prevalence of the substance over the form, provided by OIC 11.

The document is organized as follows: in chapter 2 there is the literature review of the subject under research; in chapter 3 it has described the methodology adopted; in chapter 4 the results achieved by this study and finally in chapter 5 the conclusions and implications.

This paper analyzes the impact of the application of OIC 11 in the range of Italian companies in the logistics and large distribution sector. The choice of these sectors was made to have the most representative cluster of companies most involved in the use of these types of contracts and therefore it is possible to capture the greatest incidence of the change in methodology (Beattie, Edwards, \& Goodacre, 1998; Cotei \& Farhat, 2017; Van Donselaar, Kokke, \& Allessie, 1998; Wilkins \& Zimmer, 1983). In order to aim the purpose, the data set was created with companies with the same fiscal year and with more than 15 employees. As far as the authors' knowledge is concerned, no empirical study was conducted to verify the applicability of leasing accounting through the financial method to newly established SMEs. The purpose of this study is to identify how the performance of the sector's financial statements would be modified with the introduction of the IAS 16 accounting method and also for Italian SMEs, which adopt the OICs.

This research has explored the new approach applicable since 1 January 2019, which aims to increase transparency towards international stakeholders (Toferer, 2018), enabling stakeholders, whether investors or banks, to have a greater awareness of the "real asset" related to all the conditions to be recorded in the accounts 
regarding depreciation, obsolescence, and durability. This research has also produced a reflection on the current Italian economy, regarding the effect that the adoption of the operating method can have on Italian companies on the issue of liquidity, leading to greater protection.

\section{Literature Review}

The firms, in general, follow quite heterogeneous policies regarding financing strategy (Beattie, Goodacre, \& Thomson, 2006). This assertion was justified by Beattie et al. (2006) through a survey of UK financial directors. The aim was to understand how companies determine their funding strategy and to find out why they should choose a mix of financial instruments. In addition, they tried to compare the results with existing theories on capital structure.

Leasing is an important activity for many businesses as it assists in the use of assets, obtaining finance and reducing an entity's exposure to the risks associated with business finance (IASB, 2016).

Lease capitalisation does have a material impact on financial ratios such as profitability and financial stability (Beckman \& Jervis, 2009; Bennett \& Bradbury, 2003; Durocher, 2008; Goodacre, 2003).

An important part of the recent literature regarding operating leases refers to the proposal being debated regarding the capitalisation or not of operating leases on the balance sheet. Some studies conduct ex-ante impact research that attempts to evaluate the potential impact of the changes proposed while other studies assess the effects of the proposal by means of various perspectives (Barone, Birt, \& Moya, 2014).

The literature review supports to evaluate the potential impact of including operating leases on the balance sheet both as an asset and as a liability. The studies found, through the focus on the impact in terms of key financial ratios and accounting variables, a significant impact from capitalising leases on financial ratios, these varying across different industries (Fito, Moya, \& Orgaz, 2013; Durocher, 2008; Grossmann \& Grossmann, 2010; Jesswein, 2009).

Focusing on lease capitalisation, it has a material impact on reported liabilities and financial ratios. The current ratio and ROA are the effects on the debt ratio observed. Consequently, the leverage will significantly increase while liquidity and profitability are expected to decrease (Bennett \& Bradbury, 2003).

Through UK retail companies, Goodacre (2003) focuses on the expected impact of operating lease capitalisation. The results are that leasing is a major source of finance and the finance leases result in immaterial changes. It has shown how operating leased assets represent a significant proportion of reported total assets, the major part of which is land and buildings.

In addition, the effect of this method is related to nine key performance ratios that include gearing, profitability (including profit margin, ROA and ROE), interest coverage, and assets turnover.

Another study with the same perception focuses on the retail industry and it investigates the expected impact of operating lease capitalisation. The study finds an increase in EBITDA together with a reduction in income from continuing operations and earnings per share, in addition, it finds significant increases for financial leverage and reduction for debt coverage measures, and the profitability measures ROA and ROE are also reduced (Mulford \& Gram, 2007).

The strongest impact is found in balance sheet ratios (leverage) but the impact on profitability ratios and market multiples often used for valuation purposes are only minor (Fülbier, Silva, \& Pferdehirt, 2008).

The effects of operating lease capitalisation should not be overstated, even though there is a relevant 
impact for the analysis in the balance sheet, as there is no impact on valuation.

The S\&P 500 in 2003 show how companies can "hide" billions of dollars of liabilities and enhance earnings, income, and ratios, by reporting leases as operating. However, the capitalisation proposal should be fully considered (Duke, Hsieh, \& Su, 2009).

The construction and engineering industry would be particularly affected by the change of method (Beckman \& Jervis, 2009).

Analysis of financial ratios related to leverage, profitability and interest coverage attracts a lot of researchers (Singh, 2012).

The ratios ROA and the interest coverage both fall significantly which has implications for measuring the efficiency and riskiness of the firm (Bryan, Lilien, \& Martin, 2010; A. M. Grossmann \& S. D. Grossmann, 2010; Kostolansky \& Stanko, 2011). An additional implication for firms relates to their debt covenants which may need to be rewritten to allow for the change in the debt ratio. The industries would be most affected by the capitalisation of leases and find that ROA in retail, transportation, and service sectors decreases significantly. Also, these companies show increases to their debt-to-capital ratio. It is worthwhile on this subject to analyse the research by Gavazza (2010) which conducts an analysis based on the aeronautical industry that mainly focuses on the study of the relationship between liquidity and operational financing of leasing for a sample of 14,000 aircraft. The author concludes that companies with more liquidity are more likely to enter into operating leases, having shorter operating lease periods, and are able to contract leases at more favourable rates. In addition, it is worth noting the study by Bennett and Bradbury (2003) which analysed the impact of leasing with financial method on 38 companies listed on the New Zealand Stock Exchange, in particular, the study focuses on the analysis of the debt ratio, the current ratio and ROA (Return on assets). They find out that leverage highly increases while liquidity and profitability are expected to decrease. From the analysis carried out on the sample in question, it has been verified that, contrary to the expectations deriving from the literature, operating leases do not influence the liquidity of the company: the reason is due to the fact that simultaneously the commission (in the income statement) with the respective item of debt will increase by an equivalent amount.

Another point of interest is equity, which is calculated through the difference between assets and liabilities. This analysis is closely linked to the risk and cost of capital, an important study conducted by the company's (Dhaliwal, Lee, \& Neamtiu, 2011) ex-ante and ex-post evaluations were made on the equity valuation of off-balance sheet assets or capitalize leases. Their results show that the cost of ex-ante equity capital of companies is positively correlated with the capitalisation of leases. The evidence collected is guaranteed by a double check on the information. The study included 40 companies from the logistics and large distribution in Italy. These areas were chosen because, according to the statistics (Assilea, 2018), they make greater use of leasing for the purchase of industrial warehouse.

Therefore the researchers believe that the case study defined by (Yin, 2017) is the best way to answer the research question "analyzes the impact of the application of OIC 11 in the range of Italian companies in the logistics and large distribution sector”. Company names are kept anonymous for privacy reasons.

\section{Data Sources}

The analysis is based on data provided by Bureau van Dijk Electronic Publishing's AIDA database (BvDEP) for Italy. The 40 companies have been identified with the research phases:

- selection of the sample from all Italian limited companies (LTD) established in early 2017 with at least 15 
employees;

- the selected companies have adopted the operational method of accounting for leasing.

Therefore, the test phase simulates the application of the financial methodology to the entire sample, as if they were all consolidated companies in a single balance sheet, as will be seen in the tables below.

\section{Methodology}

The study adopts the method of empirical analysis that starts from the analysis of cases, through data sets. In the case study analysis, it is not possible to control the context, but it is possible to analyze the main characteristics (Benbasat, 1984; Yin, 1994). As such, case study enables a researcher to study contemporary phenomena in a real-life setting, where boundaries between context and phenomenon tend to be blurred (Stake, 1996; Yin, 1994).

The flanking of qualitative analysis to the case guarantees the veracity of what is expressed and analysed (Glaser \& Holton, 1967).

External validity is possible thanks to the characteristics related to the deposited financial statements analyzed. The analysis and the treatment were conducted by taking into consideration also reliability as the scholars usually would need to do when talking about case studies. "Reliability" refers to the absence of random error, enabling subsequent researchers to arrive at the same insights if they conducted the study along with the same steps again (Lincoln \& Denzin, 2000). Transparency and the possibility of replicating research allow and guarantees this aspect (Leonard-Barton, 1990).

In order to choose of the information to be used for the case study, only the treatment of the leasing was considered, as it was not possible to dispose of the characteristics on the rents of real estate necessary for the consequent accounting treatment, such as, for example, the contractual duration.

The analysis is based on financial report data given by AIDA database provided by Bureau van Dijk Electronic Publishing (BvDEP) for Italy. In addition, in order to avoid misleading analyses, it has been used imputation methods for missing values at the firm level.

The steps of the research are summarized as followed:

- First of all, through Aida, the sample of reference companies was selected, opting for the logistics and large retail sectors. These sectors have been chosen because, according to the statistics (Assilea, 2018), they use leasing more for the acquisition of industrial warehouses;

- The sample was selected from all LTD Italian companies with the following reasoning: to minimize the margin of error and to make the method as healthy as possible, they have been selected only in the two sectors indicated and they have been constituted in the early months of 2017 with at least 15 employees;

- Forty companies have been selected with the same characteristics;

- The selected companies have adopted the operating method, therefore the test phase simulates the application of the finance method to the whole sample as if they were all consolidated into a single financial statement as you can see Tables 3 and 4;

- The two categories are: the companies operating in the wholesale and retail trade and repair of motor vehicles and motorcycles; selected enterprises that are involved in the wholesale trade (excluding motor vehicles and motorcycles). In addition, the selected companies have at least 15 employees. The reason of this choice is that the subjects use the leasing because of the nature of their activity, for example, there is a huge probability that they need a warehouse.

As can be seen from the figure below, the companies that are the subject of this analysis are located 
throughout the country, but the most significant contraction is in the north.

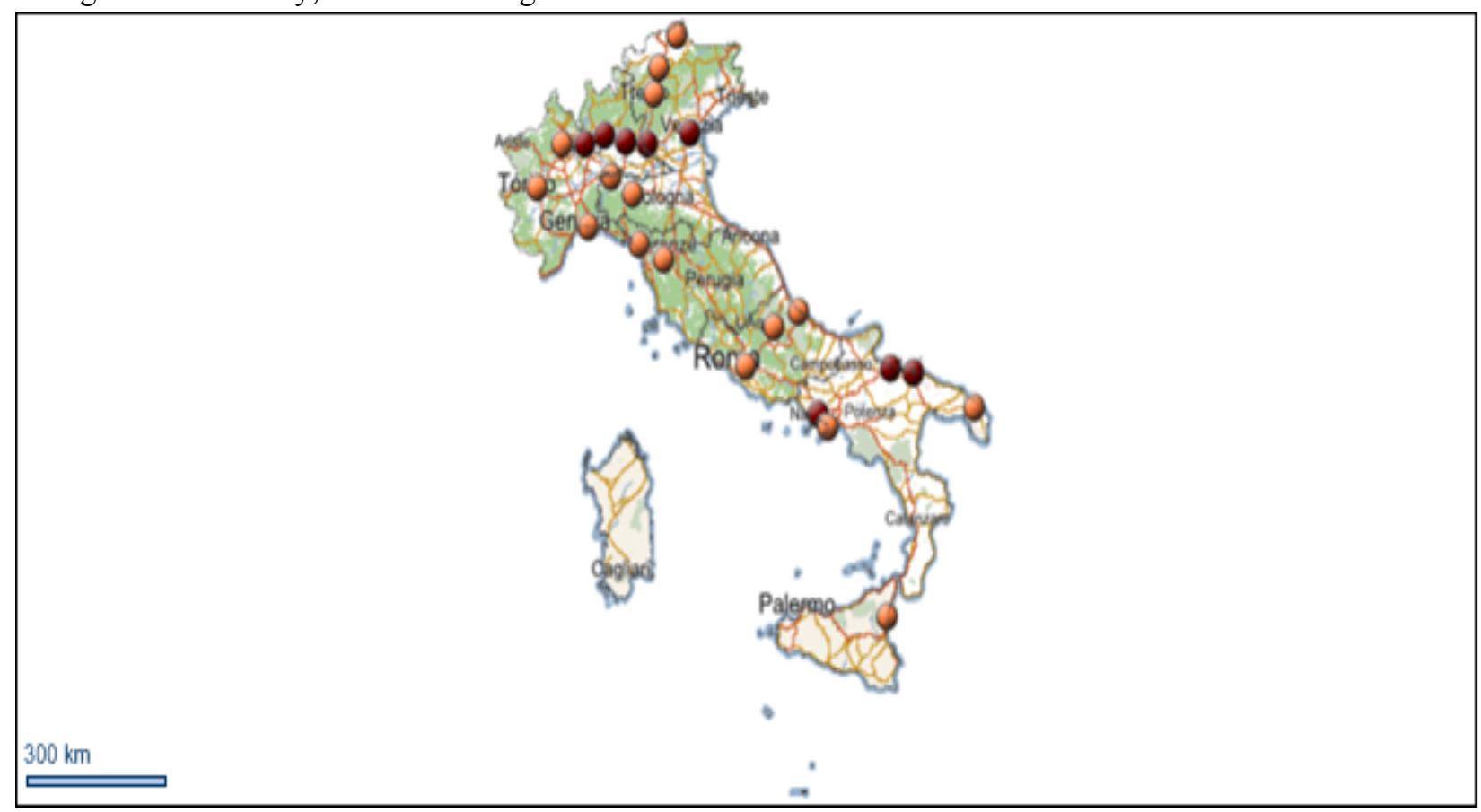

Figure 1. Distribution of enterprises in Italy. Source: Analisi Informatizzata Delle Aziende (AIDA).

The research arrived at the definition of the dataset summarized in Table 1 starting from 895,967 LTD companies still active. Refining the research, the date of establishment have been selected from the year 2017 to the year 2018 including and the number has been reduced to 107,363. In addition, focusing on the sectors of "wholesale and retail trade and repair of motor vehicles and motorcycles" and "wholesale trade (excluding motor vehicles and motorcycles)" the sample was restricted. Considering the filters explained above, on 232,628 Italian companies, only 6,751 were selected. Finally, to make the cluster more significant, it was decided to consolidate only the companies with a minimum number of 15 employees, defining a representation of 52 companies. To increase the truthfulness of the representation, only the companies that were established before June 2017 were considered and this led to the definition of the reference cluster.

The present selection of financial report clusters can be summarised from the following table:

Table 1

Summary of the Criteria Search on the AIDA Database

\begin{tabular}{ll}
\hline Juridical status & Active \\
\hline Legal form & Capital company-LTD \\
\hline Date of constitution & From 2017 to 2017 \\
\hline Activities-product classification & 45-Wholesale and retail trade and repair of motor vehicles and motorcycles \\
\cline { 2 - 2 } & 46-Wholesale trade, except of motor vehicles and motorcycles \\
\hline Financial data-income statement & B8 (costs for use of third party assets) Last Year available \\
\hline Number of employees & Minimum 15 \\
\hline Type of budget and availability & All companies with ateco 2007 financial statements \\
\hline Constitution & Than July 2017 \\
\hline Cluster & 40 companies \\
\hline
\end{tabular}

Source: Authors' production. 


\section{Findings}

Through the sample of selected Italian companies operating in the indicated product sector, the effect that the change of method will have has been simulated. The change from operating leases to finance leases generates the following effects on the balance sheet (for all the entries, the tax aspects concerning VAT value added tax are neglected):

The following accounting entry represents the recording of the operating lease (Carretta \& Fiordelisi, 2000):

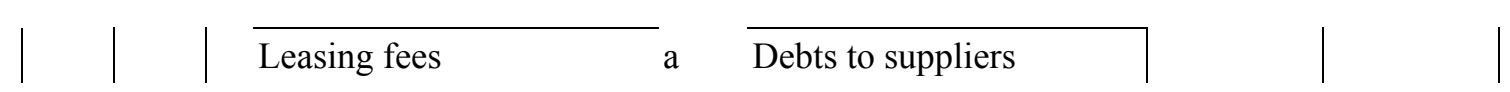

With this accounting entry, the leasing fee impacts the whole year, the asset remains out of the balance sheet, and the cost is expensed all over the year. The debt to the leasing company is recorded but limited to the portion of the leasing fee (Mellado \& Parte, 2017).

Instead, the accounting entries for accounting through the finance method, therefore according to IFRS 16 (Sacarin, 2017), are:

\section{$\overline{\text { Shed }}$ a Debts to suppliers}

The following entry, as well as the first one, i.e. when the contract is signed, is used to record the total debt due to the leasing company, recording it under the liabilities in the balance sheet. The asset (the shed) is recognised as an asset in the balance sheet:

$$
|| \begin{array}{lll}
\begin{array}{l}
\neq \\
\text { Debts to suppliers } \\
\text { Interest expense }
\end{array} & \text { a } & \text { Bank account }
\end{array} \mid
$$

This accounting entry is recorded when the instalment is paid to the leasing company; therefore, the cash exit from the bank current account is recorded, the decrease for the capital share paid to the leasing company is recorded, thus decreasing the debt recorded in the balance sheet liabilities and the part of the liabilities paid to the leasing company is recorded in the income statement (Giner \& Pardo, 2018).

At the end of the financial year, among the operations of the closure, it is necessary to record the entries of the depreciations, also the depreciation of the warehouse subject to the leasing contract. The double-entry method, is as follows (Chen, Huang, \& Ardiansyah, 2018):

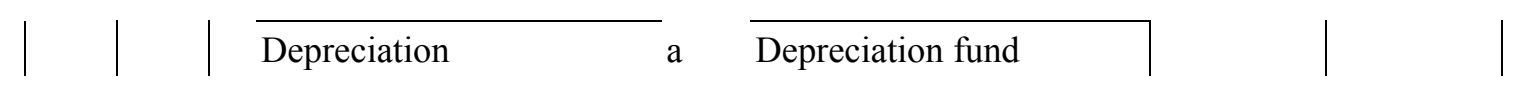

The following table shows the assumptions underlying the calculations of the balance sheet items.

The assumptions underlying this study are summarized in Table 2 . The assumptions are that the depreciation rate will be considered for the purpose of the simulation is $5 \%$ and the assumed period of the lease is 20 years. Furthermore, the relevant aggregated data of the companies that have applied operating leasing within their accounts and consequently represented in the financial statements are reported. The following is shown: what are the items that would undergo the methodological change and the economic effect? In both cases, the real aggregation data are entered and to be able to improve the understanding of the reasoning, the data are rounded. 
Table 2

Balance Sheet Items Which Would be Affected by the Change in Methodology

\begin{tabular}{lll}
\hline Leasing & & \\
\hline Typology & Shed & \\
Depreciation percentage & $5 \%$ & $5 \%$ \\
Years of lease payment & 20 years & \\
\hline Current-operating method & & Rounded \\
\hline Financial report item & & $5,000,000.00$ \\
Item B8 & $5,678,783.00$ & $-5,000,000.00$ \\
Debts & $-5,678,783.00$ & $-5,000,000.00$ \\
Bank & $-5,678,783.00$ & \\
\hline Change method-financial method & & Rounded \\
Financial report item & & $100,000,000.00$ \\
Tangible assets & $113,575,660.00$ & $100,000,000.00$ \\
Debts & $113,575,660.00$ & $-5,000,000.00$ \\
Bank & $-5,678,783.00$ & $95,000,000.00$ \\
Debts-payment & $107,896,877.00$ & $5,000,000.00$ \\
Depreciation & $5,678,783.00$ &
\end{tabular}

Source: Authors' production.

\section{Financial Reporting}

The following tables show the aggregation of all 40 budgets by macro item. The column entitled "Operating method" shows the book values using the operating method for financial accounting. The "Financial method" column is presented with the leasing accounting using the financial method.

The balance sheet items which would be affected by the change in methodology are summarised in Table 2 , underlining, the hypothesis is that the depreciation rate is $5 \%$ and lease payment in a period of 20 years. Table 3 shows the balance sheet aggregate by macro-balance sheet items, the aggregate, including the balance sheet, assets, and liabilities, and the income statement is prepared following the leasing accounting method using the Operating Method.

Table 3 shows the aggregation of all the financial statement formats with the operating method and the financial method; they have been compared and can be seen in the columns named as the method used.

Aggregation of all the financial statement formats with the operating method and the financial method compared. At a glance, it is possible to see that there are differences that will be explained later.

The difference in the income statement between the use of the leasing accounting by the operating or financial method does not impact on the profit or loss for the year. The only differences affecting the income statement are the items:

B.8. Leases and rentals, which under the financial method amount to 678,783 , unlike the operating method, which amounts to $5,678,783$;

B.10. Total depreciation and amortisation, which under the financial method is equal to $9,029,173$, whereas under the leasing method it is equal to 4,029,173.

The differences found are in line with what was expected, based on the literature analysed and the accounting standard settlements (Carretta \& Fiordelisi, 2000; Goodacre, 2003; McConnell \& Schallheim, 1983; Wilkins \& Zimmer, 1983). 
Table 3

Aggregation of All Balance Statements With Operating Method and Financial Method Compared

\begin{tabular}{|c|c|c|c|c|c|}
\hline \multicolumn{6}{|c|}{ Balance sheet } \\
\hline \multicolumn{3}{|l|}{ Assets } & \multicolumn{3}{|c|}{ Liabilities } \\
\hline & $\begin{array}{l}\text { Operating } \\
\text { method }\end{array}$ & $\begin{array}{l}\text { Financial } \\
\text { method }\end{array}$ & & $\begin{array}{l}\text { Operating } \\
\text { method }\end{array}$ & $\begin{array}{l}\text { Financial } \\
\text { method }\end{array}$ \\
\hline \multirow[t]{2}{*}{$\begin{array}{l}\text { A. Receivables from shareholders for } \\
\text { subscribed share capital not yet paid-up }\end{array}$} & $2,427,500$ & $2,427,500$ & A. Equity & $94,501,656$ & $94,501,656$ \\
\hline & & & A. IX. Profit or loss & $3,815,809$ & $3,815,809$ \\
\hline B. Total assets & $119,406,010$ & $214,406,010$ & & & \\
\hline B.I. Total intangible assets & $76,802,076$ & $76,802,076$ & $\begin{array}{l}\text { B. Risks and } \\
\text { charges fund }\end{array}$ & $22,119,241$ & $22,119,241$ \\
\hline B.II. Total tangible assets & 29.188 .617 & $124,188,617$ & C. Severance pay & $10,070,265$ & $10,070,265$ \\
\hline B.II.1. Lands and buildings & $7,853,282$ & $107,853,282$ & & & \\
\hline \multirow[t]{2}{*}{ Depreciation fund tangible assets } & $1,913,591$ & $6,913,591$ & D. Total debt & $212,664,095$ & $307,664,095$ \\
\hline & & & D.5. Other lenders & $6,886,035$ & $101,886,035$ \\
\hline \multirow[t]{2}{*}{ B.III. Total financial assets } & 13.415 .317 & 13.415 .317 & & & \\
\hline & & & $\begin{array}{l}\text { E. Accruals and } \\
\text { deferred income }\end{array}$ & 470.304 & 470.304 \\
\hline C. Current assets & $217,247,927$ & $217,247,927$ & & & \\
\hline D. Prepayments and accrued income & 744,124 & 744,124 & & & \\
\hline Total assets & $339,825,561$ & $434,825,561$ & Total liabilities & $339,825,561$ & $434,825,561$ \\
\hline
\end{tabular}

Source: Authors' production.

\begin{tabular}{lll}
\hline & Income statement & \\
\hline & Operating method & Financial method \\
\hline A. Total revenue & $248,240,204$ & $248,240,204$ \\
& & \\
B. Total expense & $242,267,582$ & $242,267,582$ \\
B.8. Leases and rentals & $5,678,783$ & 678,783 \\
B.10. Total depreciation and amortisation & $4,029,173$ & $9,029,173$ \\
B.10.b. Depreciation and amortisation tangible assets & $1,900,122$ & $6,900,122$ \\
Operating income & $5,972,622$ & $5,972,622$ \\
C. Total financial income and charges & $-159,161$ & $-159,161$ \\
D. Total adjustments assets financial & - & - \\
Earnings before tax & $5,813,461$ & $5,813,461$ \\
20. Total tax & $1.997,652$ & $1,997,652$ \\
21. Profit or loss & $\mathbf{3 , 8 1 5 , 8 0 9}$ & $\mathbf{3 , 8 1 5 , 8 0 9}$ \\
\hline
\end{tabular}

Source: Authors' production.

Table 4

Profitability Analysis

\begin{tabular}{llll}
\hline & ROE & ROI & ROA \\
\hline Operating method & $4.038 \%$ & $1.758 \%$ & $1.123 \%$ \\
Financial method & $4.038 \%$ & $1.374 \%$ & $0.878 \%$ \\
\hline
\end{tabular}

Source: Authors' production.

The most significant impact of the change in accounting is recognised in the balance sheet. In compliance with IFRS 16, capitalisation takes place through the present value of the future cash flows envisaged in the contract, thus making it possible: 
- Determine the value of the asset recorded in the Balance Sheet;

- Determine the total amount of the debt to the leasing company, registered in the Liabilities Balance Sheet.

With the above premises, it is possible to note in Table 3 the effect of the application of IFRS 16 in the accounting and they are detailed as follow:

The balance sheet item "B.II.1. Lands and buildings" with the use of the operating method were equal to $7,853,282$, while with the application of the financial method; on the other hand, the same item was equal to $107,853,282$;

With the closing entries, the depreciation of the building is accounted for, thus increasing the "Depreciation fund tangible assets" from 1,913,591 with the Operating Method to 6,913,591 with the financial method.

In the Balance Sheet, through the change in accounting method, the only item that changes is "D.5. Other lenders" which, with the Operating Method, is 6,886,035, while with the financial method it is $101,886,035$. In this case, there is no evidence of differences in shareholders' equity, because there is no effect on the income statement of the same magnitude as the effect of amortization, therefore with a change in the result for the year, through the assumptions made in the case study. Indeed, if contractual conditions and/or depreciation policies change, they could affect the result for the year and consequently also have an impact on shareholders' equity, considering that shareholders' equity includes the item "Profit or loss".

Overall, the effect of the change in accounting would have an impact on total assets (and consequently also on total liabilities) of $95,000,000$, an increase compared to the accounting of leasing with the Operating Method.

As shown above, with the improvement in ROA, an improvement in pre-tax income can be associated, therefore, resulting in a positive effect on the profit for the year. The effect would have a possible reaction on shareholders' equity, because this one as well as being derived from the difference between assets and liabilities is also equal to the sum of the share capital, reserves and result for the year, so in case of improvement in the result for the year as a result will increase the shareholders' equity. In addition, IFRS 16 also requires consideration to be given to the time element.

As Table 4 shows in the profitability analysis, ROE (return on equity) measures the overall return of the considered company in percentage terms is, therefore, an economic performance indicator (Gompers, Ishii, \& Metrick, 2003). The ROE in the case study under consideration does not vary, because both the values of shareholders' equity and profit for the year do not vary with the change of method. ROI, on the other hand, measures the economic efficiency of characteristic management (Psacharopoulos, 1994) the value of the ROI (return on investment) with the change of method decreases. It is to be attributed to the active total that increases with the change of method. ROA (return on assets) is an indicator of how profitable a company is relative to its total assets. The company's profitability is measured by the assets it owns (Kothari, Leone, \& Wasley, 2005). Contrarily to the literature that with the change of method results to increase the value, in the case study object of the analysis, it has been found a negative effect: the ROA with the change of method has decreased.

The adoption of IFRS 16 eliminates the opportunity to make a valuation choice-which provided the IAS 17-between accounting the lease with the operating method or with the financial method, thus pursuing an objective of accounting harmonization. 


\section{Conclusions and Implications}

In order to pursue the purpose of research to identify how the performance of the sector's financial statements would be modified with the introduction of the IAS 16 accounting method also for Italian SMEs, which adopt the OICs, through the case study analyzed, the change to the financial method translates into an increase in the general of the balance sheet assets and liabilities.

Representation to the stakeholder of the transaction signed by the company is linked to recognition in the financial statements. The balance sheet includes the item under assets and an obligation to pay, which will give rise to a debt recorded under liabilities.

Therefore, the stakeholder, whether the investor or the bank, has an awareness of the "real asset", with all characteristics, so that the asset is subject to depreciation, obsolescence all attributes of "durability" of the asset that falls within the corporate sphere. On the other hand, with the Operating Method, if the consultation of the explanatory notes is excluded, the reader of the financial statements has the perception of the annual cost in the income statement, but it is not clear that the expense incurred annually is for the purchase of an asset with a multi-year duration. At the same time, there is no evidence that the company, subscribing the leasing contract, will have to pay leasing instalments not only in one year but, throughout the duration of the contract which is often multi-year.

The new approach applicable from 1st of January, 2019 aims to increase transparency towards international stakeholders (Toferer, 2018), thus increasing the information provided to banks with greater ability to assess the real value of the company's assets.

The accounting of leasing, according to the financial method, has different similarities with bank debt. What mainly differentiates these two types is the transfer of ownership of the asset: with the leasing contract, the owner of the asset is the lessor for the entire duration of the contract, in addition, in the event that there is no redemption, the asset continues to be the lessor; in bank debt, however, the ownership of the asset is the user.

IFRS 16 will affect performance metrics and financial ratios such as asset turnover, gearing, current ratio, interest hedging and net income, so it is important that companies are prepared for these changes. Many lessees will see their operating cash flow increase, as only the portion of the lease payments that reflects interest on the lease liability can be presented in the financial assets.

The accounting of the contract through the operating leasing, based on the immediate treatment and in agreement with the literature, produces a saving of liquidity aspect that must be taken into consideration in the light of the liquidity difficulties that in these years has invested the Italian industrial sector. The second aspect concerning, instead, accounting through financial leasing, based on the results obtained and based on the literature available to us. It has been discovered that, through the analysis of shareholders' equity, accounting with the financial leasing method has a positive effect. Besides, the accounting of the leasing with this method contributes to a more possible exposure in the balance sheet of the operation.

The research also produced a reflection on the current Italian economy. The adoption of the operating method can help Italian companies a lot, as one of the problems currently experienced by the players in this system is related to liquidity, despite the fact that the activities produce revenues (Fabrizi, Malaspina, \& Parbonetti, 2017; Mariani, Pirani, \& Radicchi, 2013; Pace, 2013). The change of approach, in this case, could lead to the correct protection of liquidity. 
This result suggests that this accounting method for Italy would probably not have a good immediate effect, but as most reasonable legislative interventions are not retroactive.

This research could be extended in several directions. First, it would be interesting to see whether our results apply to other companies operating in different sectors. In addition, it would also like to measure the impact of leasing accounting by the financial method on industrial vehicles. Secondly, it would be interesting to see whether our results apply to different countries with different degrees of financial development. These extensions are on the agenda for future research.

\section{References}

Armstrong, C. S., Barth, M. E., Jagolinzer, A. D., \& Riedl, E. J. (2010). Market reaction to the adoption of IFRS in Europe. The Accounting Review, 85(1), 31-61. Retrieved from: https://doi.org/10.2308/accr.2010.85.1.31

Assilea, A. I. L. (2018). I numeri del leasing e del noleggio, dati 2017-2018. Recuperato da Assilea Servizi S.u.r.1. Retrieved from: https://www.assilea.it/documentazioneAction.do?idCategoria=17

Barone, E., Birt, J., \& Moya, S. (2014). Lease accounting: A review of recent literature. Accounting in Europe, 11(1), 35-54. Retrieved from: https://doi.org/10.1080/17449480.2014.903630

Beattie, V., Edwards, K., \& Goodacre, A. (1998). The impact of constructive operating lease capitalisation on key accounting ratios. Accounting and Business Research, 28(4), 233-254. Retrieved from: https://doi.org/10.1080/00014788.1998.9728913

Beattie, V., Goodacre, A., \& Thomson, S. J. (2006). International lease-Accounting reform and economic consequences: The views of U.K. users and preparers. The International Journal of Accounting, 41(1), 75-103. Retrieved from: https://doi.org/10.1016/j.intacc.2005.12.003

Beatty, A., Liao, S., \& Weber, J. (2010). Financial reporting quality, private information, monitoring, and the lease-versus-buy decision. The Accounting Review, 85(4), 1215-1238. Retrieved from: https://doi.org/10.2308/accr.2010.85.4.1215

Beckman, J. K., \& Jervis, K. (2009). The FASB-IASB lease accounting project: Implications for the construction industry. Construction Accounting and Taxation, 19(2), 30-35.

Benbasat, I. (1984). An analysis of research methodologies. The Information Systems Research Challenge, 47, 85.

Bennett, B. K., \& Bradbury, M. E. (2003). Capitalizing non-cancelable operating leases. Journal of International Financial Management \& Accounting, 14(2), 101-114. Retrieved from: https://doi.org/10.1111/1467-646X.00091

Bryan, S. H., Lilien, S., \& Martin, D. R. (2010). The financial statement effects of capitalizing operating leases. The CPA journal, $80(8), 36$.

Carretta, A., \& Fiordelisi, F. (2000). Il leasing operativo. Caratteristiche giuridiche, economiche e gestionali nei mercati europeo e statunitense e prospettive di sviluppo in Italia.

Chambers, D., \& Dooley, J. (2015). Preparing for the looming changes in lease accounting. The CPA Journal, 85(1), 38-42.

Chen, W. T., Huang, K., \& Ardiansyah, M. N. (2018). A mathematical programming model for aircraft leasing decisions. Journal of Air Transport Management, 69, 15-25. Retrieved from: https://doi.org/10.1016/j.jairtraman.2018.01.005

Cordazzo, M., Rossi, P., \& Lubian, L. (2019). Implicazioni teoriche ed empiriche del nuovo principio contabile IFRS 16 sul leasing. Franco Angeli.

Cotei, C., \& Farhat, J. (2017). The leasing decisions of startup firms. Review of Pacific Basin Financial Markets and Policies, 20(4), 1-30.

Dezzani, F., Biancone, P., \& Busso, D. (2016). IAS/IFRS. Gruppo Wolters Kluver Italia s.r.l.-IPSOA.

Duke, J. C., Hsieh, S. J., \& Su, Y. (2009). Operating and synthetic leases: Exploiting financial benefits in the post-Enron era. Advances in Accounting, 25(1), 28-39.

Durocher, S. (2008). Canadian evidence on the constructive capitalization of operating leases. Accounting Perspectives, 7(3), 227-256. Retrieved from: https://doi.org/10.1506/ap.7.3.2

Fabrizi, M., Malaspina, P., \& Parbonetti, A. (2017). Caratteristiche e modalità di gestione delle aziende criminali. Rivista di Studi e Ricerche sulla criminalità organizzata, 3(1), 47-66. Retrieved from: https://doi.org/10.13130/cross-8281

Fito, M. A., Moya, S., \& Orgaz, N. (2013). Considering the effects of operating lease capitalization on key financial ratios. Revista Espanola De Financiacion Y Contabilidad—Spanish Journal of Finance and Accounting, 42(159), 341-369.

Fülbier, R. U., Silva, J. L., \& Pferdehirt, M. H. (2008). Impact of lease capitalization on financial ratios of listed German companies. Schmalenbach Business Review, 60(2), 122-144. 
Gavazza, A. (2010). Asset liquidity and financial contracts: Evidence from aircraft leases. Journal of Financial Economics, 95(1), 62-84. Retrieved from: https://doi.org/10.1016/j.jfineco.2009.01.004

Glaser, B. G., \& Holton, J. (1967). Discovery of grounded theory.

Giner, B., \& Pardo, F. (2018). The value relevance of operating lease liabilities: Economic effects of IFRS 16. Australian Accounting Review, 28(4), 496-511. Retrieved from: https://doi.org/10.1111/auar.12233

Gompers, P., Ishii, J., \& Metrick, A. (2003). Corporate governance and equity prices. The Quarterly Journal of Economics, 118(1), 107-155. Recuperato da JSTOR.

Goodacre, A. (2003). Operating lease finance in the UK retail sector. The International Review of Retail, Distribution and Consumer Research, 13(1), 99-125. Retrieved from: https://doi.org/10.1080/0959396032000065373

Graham, R. C., \& King, R. D. (2013). Decision usefulness of whole-asset operating lease capitalizations. Advances in Accounting, 29(1), 60-73.

Grossmann, A. M., \& Grossmann, S. D. (2010). Capitalizing lease payments: Potential effects of the FASB/IASB plan. The CPA Journal, 80, 6-11.

IASB. International Financial Reporting Standard-16 Leases (IFRS 16). , 9 (2016).

Jesswein, K. R. (2009). Analyzing creditworthiness from financial statements in the presence of operating leases. Academy of Accounting and Financial Studies Journal, 13(1), 75.

Joubert, M., Garvie, L., \& Parle, G. (2017). Implications of the New Accounting Standard for Leases AASB 16 (IFRS 16) with the inclusion of operating leases in the balance sheet. The Journal of New Business Ideas \& Trends, 15(2), 1-11.

Kostolansky, J., \& Stanko, B. (2011). The joint FASB/IASB lease project: Discussion and industry implications. Journal of Business and Economics Research, 9(9), 29-36.

Kothari, S. P., Leone, A. J., \& Wasley, C. E. (2005). Performance matched discretionary accrual measures. Journal of Accounting and Economics, 39(1), 163-197. Retrieved from: https://doi.org/10.1016/j.jacceco.2004.11.002

Leonard-Barton, D. (1990). A dual methodology for case studies: Synergistic use of a longitudinal single site with replicated multiple sites. Organization Science, 1(3), 248-266.

Lightner, K. M., Bosco, B., DeBoskey, D. G., \& Lightner, S. M. (2013). A better approach to lease accounting: Fixing the shortcomings of the proposed rules. The CPA Journal, 83(9), 14-25.

Lincoln, Y. S., \& Denzin, N. K. (2000). The handbook of qualitative research. SAGE publication.

Mariani, M., Pirani, E., \& Radicchi, E. (2013). La sopravvivenza delle imprese negli anni della crisi: prime evidenze empiriche dalla Toscana. ECONOMIA E POLITICA INDUSTRIALE. Retrieved from: https://doi.org/10.3280/POLI2013-001002

McConnell, J. J., \& Schallheim, J. S. (1983). Valuation of asset leasing contracts. Journal of Financial Economics, 12(2), $237-261$. Retrieved from: https://doi.org/10.1016/0304-405X(83)90037-5

Mechelli, A. (2009). Accounting harmonization and compliance in applying IASB Standards: An empirical survey about the first time adoption of IAS 7 by Italian listed groups. Accounting in Europe, 6(2), 231-270. Retrieved from: https://doi.org/10.1080/17449480903172077

Mellado, L., \& Parte, L. (2017). Determinants of corporate lobbying intensity in the lease standard-setting process. Revista de Contabilidad, 20(2), 131-142. Retrieved from: https://doi.org/10.1016/j.rcsar.2016.09.001

Morales-Díaz, J., \& Zamora-Ramírez, C. (2018). The impact of IFRS 16 on key financial ratios: A new methodological approach. Accounting in Europe, 15(1), 105-133. Retrieved from: https://doi.org/10.1080/17449480.2018.1433307

Mulford, C. W., \& Gram, M. (2007). The effects of lease capitalization on various financial measures: An analysis of the retail industry. The Journal of Applied Research in Accounting, 2(2), 3-13.

Öztürk, M., \& Serçemeli, M. (2016). Impact of new standard "IFRS 16 Leases" on statement of financial position and key ratios: A case study on an airline company in Turkey. Business and Economics Research Journal, 7(4), 143.

Pace, R. (2013). Piccole e micro imprese italiane tra crisi e vincoli finanziari: un'indagine empirica. Piccola Impresa/Small Business, O(1). Retrieved from: https://doi.org/10.14596/pisb.132

Psacharopoulos, G. (1994). Returns to investment in education: A global update. World Development, 22(9), $1325-1343$. Retrieved from: https://doi.org/10.1016/0305-750X(94)90007-8

Repubblica Italiana. (1942). Codice civile (Regio Decreto 16 marzo 1942, n. 262).

Repubblica Italiana. (2015). Decreto legislativo del 18/08/2015 n. 139 - Attuazione della direttiva 2013/34/UE relativa ai bilanci d'esercizio, ai bilanci consolidati e alle relative relazioni di talune tipologie di imprese, recante modifica della direttiva 2006/43/CE e abrogazione delle direttive 78/660/CEE e 83/349/CEE, per la parte relativa alla disciplina del bilancio di esercizio e di quello consolidato per le societa' di capitali e gli altri soggetti individuati dalla legge. 
Sacarin, M. (2017). IFRS 16 "Leases"-Consequences on the financial statements and financial indicators. Audit Financiar, 15(145), 114-122.

Singh, A. (2012). Proposed lease accounting changes: Implications for the restaurant and retail industries. Journal of Hospitality \& Tourism Research, 36(3), 335-365. Retrieved from: https://doi.org/10.1177/1096348010388659

Stake, R. E. (1996). The art of case study research. Thousand Oaks, CA: SAGE Publications (ISBN 0-8039-5767-X). Library \& Information Science Research, 18(3), 291-293. Retrieved from: https://doi.org/10.1016/S0740-8188(96)90053-5

Toferer, W. (2018). Der Übergang von IAS 17 auf IFRS 16: Versuch einer Abschätzung der bilanziellen Auswirkungen. Gabler.

Van Donselaar, K., Kokke, K., \& Allessie, M. (1998). Performance measurement in the transportation and distribution sector. International Journal of Physical Distribution \& Logistics Management.

Wilkins, T., \& Zimmer, I. (1983). The effect of leasing and different methods of accounting for leases on credit evaluations. The Accounting Review, 58(4), 749-764.

Yin, R. K. (1994). Case study research: Design and methods. SAGE publications. 